\title{
THE ANALYSIS OF FREIGHT TRANSPORTATION COST OF SUPERIOR COMMODITIES IN EAST JAVA
}

\author{
Kariyoto \\ Vocational Education Brawijaya University in Malang, \\ Jl. Veteran 12-16 Malang 65145 HP 085755563811 , \\ Email: kariyoto@ub.ac, id
}

\begin{abstract}
Transport has a strategic role in the effort to support the development of Indonesia. Transportation directly affects the opening of opportunity leading to a wider market, on time delivery and price efficiency. The influence is not directly related to the multiplier effect which the price of commodities or services can go down and diversity of commodities can increase. The purpose of this study, to analyze the operational costs of freight transport suprior commodity in East Java. Qualitative research approach used to analyze the operational costs of freight transport, to identify the components of the cost of transport of goods using a landline as well as to analyze the contribution of freight vehicles operating costs of setting a selling price of superior commodity in East Java province. The results of the research that the operational costs of vehicles in Indonesia is higher compared to the average vehicle operating costs in the region. Vehicle operating costs in East Java is highly depend on the type of truck, tonnage transported. The highets costs in operating costs freight vehicles are fuel oil (BBM), depreciation costs and wage costs while the cost of driver salary while parts also highly influence on vehicle operating costs. The cost of fuel is influenced by the topography and road conditions of the route from Surabaya to Malang.

Keywords: transportation, cost transportation of goods, leading commodity.
\end{abstract}

\section{INTRODUCTION}

Transport has a strategic role in the effort to support the development of Indonesia. The existence of transport will have an impact on quality of life, both in the field of socio-cultural, political, economicand security. In the Law of the Republic of Indonesia number 22 of 2009 on traffic and road transport stated that traffic and road transport has a strategic role in supporting the development and national integration as part of efforts to promote public welfare as mandated by the Constitution of the Republic of Indonesia in 1945. As part of the national transportation system, road freight should be developed potential and its role in supporting economic development. In line with this, the Government of Indonesia in 2015-2019 RPJMN has been mandated to build infrastructure, improve the effectiveness of the transportation performance, and system settings. Transport done because of the limited ability of a region in fulfiling needs of society, so that by using transport can reach the destination and create / increase 
the utility or usefulness of goods transported. Transport it self can influence directly and indirectly to the economy. Direct influence is increasingly opening up opportunities to go to the broader market, on time delivery and affect the efficiency of the price. While in directlyinfluence related to the effect of the multiplier effect (economy double) where pricescommodity or service can go down and diversity of commodities can increase. However, based on the publication published by Bank Indonesia, Indonesia recently is still facing the condition of the gap between regions in the facilities infrastructure and means of transportation, thus causing disruption in the distribution and raises the price disparity, rising prices and public inflation expectations as well as inhibiting the acceleration of infrastructure development for increasing prosperity. In addition to the disruption in the distribution, the influence of the distribution chain and the increase in distribution costs also affecton the movement of goods.

The level of efficiency of the distribution system needs to be considered because it may affect the cost of distribution, pricing and competitiveness of a commodity. The transport system is functioning properly will facilitate the distribution process. According to the American Marketing Association definition of economic distribution is study of how production factors may affect the price in the market, such as the determination of rental prices, wages, interest and profit. There are several things that must be considered in the distribution system one of which concerns the distribution channel. Distribution channels are institutions distributor or dealer institutions that have activities to deliver goods or services from producers to consumers. Based on the Law of the Republic of Indonesia Number 7 of 2014 concerning trade states that building in economics directed and implemented to promote the general welfare through the implementation of economic democracy with the principles of togetherness, efficiency, sustainability and environmental insight, independence, and balancing progress and economic unity national as mandated by the Constitution of the Republic of Indonesia in 1945. Trade is very important in improving economic development, but the development has not been fulfilling the need to face the challenges of national development so that the necessary political alignments economic provide more opportunities, support, and economic development of the people which includes cooperatives and micro, small and medium enterprises as the main pillar of national economic development. Trade is servies of events related to the transaction of goods and/or services in the country and beyond the borders of the country with the purpose of the transfer of rights to the Goods and/or Services to obtain remuneration or compensation.

Some studies show that $80 \%$ of the journey of goods made in the city leading to a residential area; indicates that housing is the dominant local consumption. Nevertheless, it should be noted that a large number of trips it only represents $20 \%$ of the total number of kilometers journey. This indicates that more goods travel patterns dominated more by a trip to the other areas, ie to the distribution center (market) or to the industrial area. The results showed that in terms of the number of kilometers traveled, travel goods to the region and from the region is the largest industry, which is quite a long journey.

Transportation in the macroeconomic has a role in building and strengthening national or regional economies and affect the development of land and other resources.

Vol. 24, No. 1/ August 2016 
This is because the transport properties have characters derived demand (derived demand), in other words transport may increase the demand on other goods. Transportation in some developed countries contribute for between $6 \%$ and $12 \%$ of Gross Domemetics Product 9GDP). However, the transport sector in Indonesia is the largest contributor to the deficit balance of trade in services, one of the causes are still many logistics companies are foreign flagged, thus give contribution to the import of transport services is quite large, on the other hand, the ratio of export of Indonesian services to GDP seen growing increased.In addition, poor infrastructure is one key that led to high logistics costs and low competitiveness of the Indonesian economy.

\section{LITERATURE}

According Tamin (2000) economically, inefficient system of transportation or transportation problems is a huge waste, because the travel patterns of different items with the travel patterns of people, the travel patterns of goods is influenced by the activity of production and consumption is highly dependent on the distribution pattern of land use settlement (consumption), as well as industry and agriculture (production). In addition, the travel patterns of goods is influenced by the pattern of the distribution chain that to lead product centre to consumption areas.

Arvist at al (2010) Logistics perfomrance index (LPI) Indonesia when compared with the closest neighboring countries it is still not optimal. In 2014 LPI ranks Indonesia ranked $53^{\text {rd }}$ out of 160 countries. While Singapore is in the $5^{\text {th }}$ position, Malaysia 25 th, Thailand and Vietnam 35 position to be at $48^{\text {th }}$ position. Based on a study conducted LPEM- FEUI (2009) found that logistics costs Indonesia is about 14\% of total production costs, compared to best practice in Japan is only 4.88 percent. The average of vehicle operating costs in the provision contained in Indonesia is estimated at Rp 3,093 per kilometer. This is higher than the Asian average, which is around US $\$ 0.22$ per kilometer. The low quality of the roads is also an obstacle to integrate the poor areas and remote with larger markets. The high cost and the long time required to reach the market significantly reduce corporate profits and may significantly reduce the chances of economic gains/profits.

Land transportation costs become the largest component of logistics costs in Indonesia, namely $66.8 \%$, the rest is administarasi costs and inventory handling costs as well as coupled with the cost of loading and unloading, parking, up to extortion. Such a situation is a big threat to the sovereignty of logistics and national competitiveness.

Integrated logistics network among ASEAN countries will be enacted in 2015, and in 2020 will enter the global logistics network. Good infrastructure is expected to boost the growth of the national economy, as revealed by the Chairman of Kadin Indonesia that Indonesia's economic growth could exceed $7 \%$ when supported by adequate infrastructure growth.

East Java Province is one of the largest centers of economic growth in the region of Java island. East Java province geographically and economically is the gateway to eastern Indonesia. In the eastern part of Indonesia, the economic role of East Java province is the largest. Of spatial and economic aspects, East Java province holds the potential huge resources, both natural and human resources.

From the economic aspect, the province of East Java province is one who contributed greatly to the national economy after the province of Jakarta. East Java's 
economic growth rate is the best compared with other provincial areas this percentage figure derived from the growth of trade between regions / inter-island among provinces in 2013 amounted to $14.77 \%$ and the number of business units as many as 803453 units. The contribution of economic growth in East Java is largely derived from the growth of the three major economic sectors, namely trade, hotels and restaurants, the manufacturing industry and the agricultural sector. Along with the growth of the economy in JavaThis East, it is only logical if the government's attention focused on efforts to improve aspects of supporting the development of one of which is the improvement in the transport sector in this particular case is to transport the goods.

\section{RESEARCH METHODS}

The approach used in this study is a qualitative approach. This study analyzed the operational costs of freight vehicles, identify the components of the cost of the transport of goods using landline and analyze the contribution of freight vehicles operating costs of setting a selling price of superior commodity in East Java province.

The data source of this researchis primaryand secondary data. Data obtained through three types of surveys. The first is a survey to the owner or manager of transportation of goods, the survey was conducted in-depth interviews. Secondly is a survey of goods transport drivers and the third a survey at the weigh stations located in East Java

The model of the research is by using questionnaires or questionnaires. The questionnaire was structured techniques to obtain data that consists of a series of written or verbal questions are answered respondents. Questionnaire method done by spreading a written list of questions compiled in a structured by related the necessary information, which can used as the data is processed. Questionnaires can be given in private, to the respondents or transmitted electronically. In this study, a questionnaire will be given distributed personally to the respondents.

\section{RESULTS AND DISCUSSION Vehicle Operating Costs}

Vehicle operating costs are factors associated with the operation of the vehicle normal conditions for a particular purpose. Based on economic considerations, it is neededa balance the tariff (reception). Vehicle operating costs can be defined as the total costs required to operate a vehicle on a traffic and road conditions for a type of vehicle per kilometer. Unit operating costs are rupiah vehicles per kilometer. Vehicle operating costs is the total cost incurred by road users to use a particular mode of the zone of origin to destination zone. In this case the entrepreneur earn a reasonable profit and can guarantee the survival and development of enterprises and public transport management. The operational cost is the cost of the main business companies other than cost of goods sold. Operating expenses consist of cost of sales, general and administrative expenses. Component of vehicle operating costs are divided into three groups, namely fixed costs (fixed costs), costs are not fixed (variable cost) and overhead costs. This study only observed at fixed costs and variable costs. Vehicle operating cost is the total cost incurred by road users to use a particular mode of the zone of origin to 
destination zone. Vehicle operating cost consists of two components: fixed costs and variable costs. Fixed costs are costs that do not change (fixed despite changes in volume production services to a certain level), while variable costs are costs that change if there is a change in the volume of production services.

\section{Superior Commodity}

Regional economic development, requires a data inventory of potential areas/communities/ areas is absolutely needed in order to set policy development patterns both sectoral and multisectoral manner. One step inventory/identification of the economic potential of the region is to identify products or potential commodities, and the mainstay of the respective regions in each sub-sector. Associated with the distribution and development of commodity prices, one of the detection of food security initiative is how the relative development of commodity prices. The price developments will affect the ability of private consumption, commodity price fluctuations will impact the market system instability, error encourage expectations and also have a negative impact on people's purchasing power.

Commodity or superior product capabilities portrait of product areas, creating value, utilize resources in real time, provide employment opportunities, generate income for the community and the government, have prospects for improving productivity and investment. A commodity or product is said to be superior if it has the competitiveness to be able to ward off competitors product or commodity in the domestic market and/or penetrate the export market.

Main commodity is a commodity that is most favorable for cultivated or developed on an area Excellent commodity agribusiness agrobusiness interpreted as commodity base that produced excessively in the sense of more to be used by people in a particular area, so that the excess can be sold out of the region. Thecriteriaof superior commodities as follows:

1. Having a fairly prominent technological content and innovative both agriculture and small industries and services.

2. Havinga comprehensive range of marketing, whether local, national mapun exports.

3. Having a characteristic of the area and involve the community at large (local workers), as well as having a high content of local raw materials.

4. Having a guarantee that a lot of local raw materials and stable or through cultivation.

5. Environmentally friendly and can promote local cultivation.

6. Having guarantees and content of the raw materials are quite a lot, stable, and sustainable.

7. Economically advantageous and beneficial to increase revenues and the ability of human society.

They are 35 most beneficial superio commodities in East Java for are attempting or developed in an area that has market prospects and was able to increase the income or welfare of farmers and families, as well as having the potential resources enough land. 


\section{Land Line Good Trasport Cost Component}

In this analysis study research of land line good transport cost, there are that have contributed to the cost of transportation of goods. Modes of land transport is the most dominant mode of transportation on the island of Java, which is used to transport goods. Transportation costs are the decisive factor in determining rates of transport activities and tools in order to control the operation reached levels as efficiently and effectively as possible. Rates are the price or value of the compensation to be paid by consumers on the consumption of a service product . Rates for a transportation service provider (operator) is the price of the services given. While for users, the tariff is the cost to be paid for services he had used. In Analysis Study of Freight Transport in East Java thre are some components are used as a determining factor, namely: use of fuel, consumption transmissionoil, consumptionengineoil, consumptionoilgardan, grease, brake fluid, oilfilter, airfilter, wages servis, fees servicing (per vehicle), overhaul engine, overhauled body, adding the engine oil, the economic life of the vehicle, the cost of BAN, fee levy, driver operating expenses, conduction of expenses, salary/wages driver per month, salary/ wages conductor per month, insurance, security services, vehiclesprice, residual price and depreciation costs. Here is the definition of the components of the cost of transportation of goods overland.

\section{Freight Vehicle Operating Costs and Contributions Freight Vehicle Operating Costs Of Selling Price}

Transport plays an important role in the growth of the economy, especially the urban. The growth of freight transport in recent decades is remarkable so it is necessary to take measures to optimize the transport of the goods. In the process, changing perceptions about logistics, logistics perceived no longer an item is needed, but the process of procuring goods are perceived as logistics needs.

In the process of supplyin good, various activities have to be passed. Starting from the location where the raw materials are produced and is transported to the place of processing to make finished material and then distributed to customers that are spread throughout the place must be made through an efficient, precise benefits in a short time so that the product price can be affordable by the consumers. The following is an operating cost of freight transport and the contribution of the operational costs of freight transport vehicles to the total sale price for the whole commodity.

The results showed operating cost of freight of 35 commodities gained overall total cost per $\mathrm{km}$ of $\mathrm{Rp} 5257.7$ it can be said that to do one trip route Surabaya - Malang need fee of USD $5257.4 / \mathrm{km}$. While for the total cost per rate (Journey Home - Go) for These Surabaya - Malang with a total distance of $200 \mathrm{~km}$, the cost of Rp1.051.530. In the implementation of freight activity, the cost component that has the largest proportion of fuel consumption amounting to Rp $1699.4 / \mathrm{km}$, while the component has the smallest proportion of the air filter at a cost of US $\$ 1.51 / \mathrm{km}$. The proportion of the cost of the air filter is relatively small because the frequency of component replacement has a long enough time interval that is for once in 1 year, assuming 25 working days and a distance of $200 \mathrm{~km}$. 
Table 4.1 Cost of Goods Transport Based Commodity Average Per Km.

\begin{tabular}{|c|c|c|}
\hline Number & Commodity Cost & Per Km \\
\hline 1 & Transport & Rp5.935 \\
\hline 2 & Building Materials & Rp5.647 \\
\hline 3 & Chemicals & Rp4.752 \\
\hline 4 & Used Goods & Rp4.982 \\
\hline 5 & Item from of the furrows nonmetallic & Rp6.271 \\
\hline 6 & Articles of rubber & Rp4.837 \\
\hline 7 & Articles of timber/forest products other & Rp5.612 \\
\hline 8 & Articles of leather/footwear & Rp4.716 \\
\hline 9 & Petrol/LPG & Rp4.550 \\
\hline 10 & Rice & Rp5.107 \\
\hline 11 & Fruits/Coconut/Coffee & Rp4.687 \\
\hline 12 & Beef/Chicken & Rp4.751 \\
\hline 13 & Salt & Rp4.703 \\
\hline 14 & Sugar & Rp5.564 \\
\hline 15 & Fish & Rp4.612 \\
\hline 16 & Corn & Rp4.695 \\
\hline 17 & Paper and Printed Matter & Rp5.345 \\
\hline 18 & Basic Metal Iron and Steel & Rp5.016 \\
\hline 19 & Food & Rp4.978 \\
\hline 20 & Furniture & Rp4.370 \\
\hline 21 & Machines and Fittings & Rp5.072 \\
\hline 22 & Drinks & Rp5.504 \\
\hline 23 & Edible Oils/Margarine & Rp4.158 \\
\hline 24 & Feed & Rp5.242 \\
\hline 25 & Palen & Rp5.099 \\
\hline 26 & Polowijo & Rp6.151 \\
\hline 27 & Fertilizer & Rp5.355 \\
\hline 28 & Cigarettes/Tobacco & Rp5.515 \\
\hline 29 & Vegetables & Rp4.472 \\
\hline 30 & Cement & Rp5.452 \\
\hline 31 & Milk Cow & Rp5.451 \\
\hline 32 & Cane & Rp5.018 \\
\hline 33 & Textile & Rp6.724 \\
\hline 34 & Chicken Eggs & Rp4.653 \\
\hline 35 & Flour & Rp4.758 \\
\hline
\end{tabular}

Source: Processed Data

Based on the above table it can be seen the average cost per $\mathrm{km}$ for each commodity route Surabaya-Malang. Commodities with transport costs are the highest 
average of textiles, while thethe lowest average commodity at a cost of freight is cooking oil. Based on the survey results for the Study of Freight Transport Cost Analysis in East Java oil as a commodity at a cost of freight lowest average since only carried by one type of vehicle so there is no comparison to other vehicle types.

\section{CONCLUSION}

The results show, vehicle operating costs varies greatly in East Java. Vehicle operating costs vary depend on the type of truck and the tonnage transported. The hoghest costs in operating costs freight vehicles are fuel oil (BBM), depreciation costs and wage costs while the cost of driver tire/parts also considerable influence on vehicle operating costs.

Vehicle operating cost estimation was done by using data obtained from a survey of trucks on the weighbridge Singosari and route the main line section of Surabaya-Malang. Based on these survey results can be seen that the operational costs of vehicles in Indonesia's Surabaya-Malang path less higher when compared to the average vehicle operating costs in the region.

The cost of fuel is influenced by the topography and road conditions of the route that bypassed that route Surabaya-Malang. Vehicle operating costs are affected by the rise and fall, the amount of rise and fall, horizontal curves, elevation and roughness ofroad surface that is road conditions Surabaya-Malang route:

The info above can be seen that the topography and road conditions affect the cost of maintenance and fuel oil. Rough road surface also affects the maintenance costs of freight vehicles and the whole also affect the operating costs of the vehicle. In other words, the road infrastructure in good condition has a significant role in reducing the cost of shipping, beside thatwith a good road infrastructure can improve the competitiveness of the region. Another factor influencing the high operational costs of vehicles is the jammeal traffic that occurs on the route Surabaya of Malang.

High operating cost of vehicles by the leading commodity in East Java depending on the superior commodity itself. For more perishable commodities and need moe places (bulky) in the transport of spending more fuel. It is different with commodities produced and distributed by industry /companies such as cooking oil and chemicals.

The other findings is the level of awareness of insurance tends to be low, this can be seen in the survey where the average cargo company did not insure his vehicle. Particularly for motor vehicle insurance is something quite important considering the motor vehicle is a good investment for the lives so many people use insurance companies to transfer risk that occurs in their motor vehicle from unwanted incidents. Risks involved in motor vehicle insurance can become more complex. This is due to the heterogeneity of the magnitude of the claim and the amount of claims on the risks that occur such as accidents or loss the vehicle in the period. The scope of the protection of motor vehicle insurance is divided into three (3) categories, namely category of minimum protection that is protection in case of an accident on the insured, the category of third party protection in case of an accident on the insured and the damage to the insured vehicle and category of protection against all risks of car ownership such as an

Vol. 24, No. 1/ August 2016 
accident,damage, fire, theft, and others. In the insurance industry claims is often a problem for consumers policyholders, therefore, the insurance industry is expected to improve transparency in accordance with the Act 8 of 1999 on consumer protection. Payment of claims with the problem can be caused by several things, not only from the insurance company, mistakes can occur in consumer policyholder due to dishonesty in providing real data before it became policyholders. Besidesthat the difficulties in the payment of claims may occur due to a lack of understanding of the insured person in the claims handling procedures and processes, it is then often leads to the assumption that the insurer looks to slow down and complicate the settlement of claims filed by the insured. Such presumption can cause people's reluctance to use the insurance.

In addition to the Freight Transport Cost Analysis Study in East Java, the providers of courier / transport of goods use security services as a substitute of insurance in order to reduce the risks that occur during the course so as to minimize losses. Therefore, it necesssary to promote the insurance industry is a series of strong government regulation. This one factor must be recognized is still weak, especially in terms of protection for customers. Why protection for policyholders on customers have to be strong because they are the owners of the funds managed by insurance providers. They also get the benefit in the future.

\section{SUGGESTION}

Transportation in the macroeconomic role in building and strengthening national or regional economy of East Java and the effect on the development of land and other resources. This is because the transport has characteristics, derived demand, in other words transport may increase the demand on other goods. Transportation in some developed countries contributed for a high GDP. However, the transport sector in Indonesia is the largest contributor to the deficit balance of trade in services, one of the causes are still many logistics companies are foreign flagged, thus contributing to the import of transport services is quite large, on the other hand, the ratio of services exports of Indonesia's GDP seen growing increased. In addition, poor infrastructure is one key that led to high logistics costs and low competitiveness of the Indonesian economy.

The low quality of the roads is also an obstacle to integrate the poorand remote areas with larger markets. The high cost and the time duration required to reach the market significantly reduce corporate profits and may significantly reduce the chances of economic gains.Along with the economic growth in East Java, it is only logical that the government's attention focused on efforts to improve aspects of supporting the development of one of which is the improvement in the transport sector that is transport the goods.

\section{ACKNOWLEDGMENTS}

Researcher would like to thank profusely to:

1. Bepeda East Java Province

2. Rector of Brawijaya University Prof. Dr. Ir. Mohammad Bisri, MS

3. The Chairman of the UB Prof. LPPM Dr. Ir. WoroBusono, MS. 


\section{REFERENCES}

Arvis J-F, Mustra, Ojala et al. 2010. Trade Logistics in the Global Economy. Washington, DC: The World Bank.

Bappenas. 2014. National Medium Term Development Plan 2015-2019. Jakarta.

International LPI Global Ranking, 2014.Global Rankings 2014. (C) 2016 The World Bank Group, All Rights Reserved.

LPEM- FEUI. 2009. The regulation, bureaucracy, and Infrastructure Hampers Logistics: Sea Transport Offers Not Developed. Jakarta. Gramedia

Patunru at.al 2009.Economic Growth, Income Inequality, and Poverty: Poverty Elasticity Parameter Estimation provincial level in Indonesia in 2004-2009. University of Indonesia. Jakarta

Law No. 22, 2009. About Traffic and Road Transportation. Yogyakarta.Reader Yustisia. Law No. 7 2014. On Trade. Jakarta. Gramedia.

Tamin, Ofyar Z. 2000.Planning and Transport Modeling.ITB. Bandung. 